\title{
UMA CRÍTICA AO POSITIVISMO JURÍDICO E À DISCRICIONARIEDADE JUDICIAL À LUZ DA OBRA MEDIDA POR MEDIDA, DE SHAKESPEARE
}

\section{ONE TO CRITICISM POSITIVISM LEGAL AND JUDICIAL DISCRETION IN THE LIGHT OF THE WORK "MEASURE FOR MEASURE" SHAKESPEARE}

\author{
${ }^{1}$ Marcelo Cacinotti Costa \\ ${ }^{2}$ Vinicius de Melo Lima
}

\section{RESUMO}

O estudo em tela pretende, no horizonte traçado em Medida por Medida, de Shakespeare, desenvolver uma crítica ao positivismo jurídico e à discricionariedade judicial, tendo por base estudo de caso, consistente na fundamentação lançada pelo Tribunal de Justiça do Rio Grande do Sul em caso referente ao genro que mata o sogro e que pretende o direito à meação da herança. O referencial teórico do artigo consiste na filosofia hermenêutica e na hermenêutica filosófica (Heidegger/Gadamer), no Direito como Integridade (Dworkin) e na Crítica Hermenêutica do Direito (Streck), em uma (necessária) aproximação entre o Direito e a Literatura para a produção de decisões constitucionalmente adequadas.

Palavras-chave: Direito e literatura, medida por medida (shakespeare), Positivismo jurídico, Discricionariedade judicial, Decisões adequadas à constituição

\begin{abstract}
The study aims to screen, in tracing the horizon in "Measure for Measure" by Shakespeare, develop a critique of legal positivism and judicial discretion, with the case study basis, consistent in the reasons released by the Court of Rio Grande do Sul if referring to the son in law that kills the father and want the right to sharecropping inheritance. The theoretical framework of the paper is the hermeneutical philosophy and philosophical hermeneutics (Heidegger/Gadamer), the Law as Integrity (Dworkin) and Critical Hermeneutics of law (Streck), in a (required) approach between Law and Literature for production constitutionally appropriate decisions.
\end{abstract}

Keywords: Law and literature, "measure for measure" (shakespeare), Legal positivism, Judicial discretion, Decisions appropriate to the constitution

\footnotetext{
${ }^{1}$ Doutor em Direito pela Universidade do Vale do Rio dos Sinos - UNISINOS, Rio Grande do Sul (Brasil). Professor de Direito Processual Civil pela Universidade de Cruz Alta - UNICRUZ, Rio Grande do Sul (Brasil). E-mail: mccacinotti@hotmail.com

${ }^{2}$ Doutor em Direito pela Universidade do Vale do Rio dos Sinos - UNISINOS, Rio Grande do Sul (Brasil). Professor de Processo Penal pela Fundação Escola Superior do Ministério Público - FESMP, Rio Grande do Sul (Brasil). E-mail: viniciuslima@mp.rs.gov.br
} 


\section{NOTAS INTRODUTÓRIAS}

A aproximação entre o Direito e a Literatura é de fundamental relevância para a compreensão de temas jurídicos complexos, em especial as decisões adotadas pelos tribunais, de modo que a doutrina exerça seu papel crítico-reflexivo.

Nesse sentido, a doutrina não pode ser meramente caudatária das decisões dos tribunais (Streck), razão pela qual é preciso jogar luz no tema da decisão jurídica democrática e suas "medidas", a partir da obra "Medida por Medida", de Shakespeare.

Tomando-se como base da discussão o estudo de caso consistente na decisão do Tribunal de Justiça do Rio Grande do Sul, em processo no qual o genro que matou o próprio sogro pretendia o direito à meação da herança, são analisados os "modelos" de fundamentação judicial e de positivismo jurídico, na perspectiva de Ângelo I e Ângelo II, na obra de Shakespeare.

A crítica ao positivismo jurídico e suas modalidades centra-se principalmente no poder discricionário judicial, razão pela qual a leitura do Direito à luz da Literatura exerce contributo valioso para o debate ora proposto, o qual tem como referencial teórico a Filosofia Hermenêutica e a Hermenêutica Filosófica (Heidegger-Gadamer), a Teoria Integrativa do Direito (Dworkin), no horizonte da Crítica Hermenêutica do Direito (Streck).

\section{1. "MEDIDA POR MEDIDA" ENTRE A METAFÍSICA CLÁSSICA E A} FILOSOFIA DA CONSCIÊNCIA: OS PARADIGMAS FILOSÓFICOS NO DIREITO

Da metafísica clássica e da visão objetivista do Direito (concepção aristotélico-tomista), percorreu-se o caminho inverso, isto é, rumo à filosofia da consciência, à semelhança da obra "Medida por Medida", de Shakespeare.

Na mencionada peça, percebe-se que o governador Ângelo, ao analisar a conduta praticada por Cláudio - condenado por "crime de luxúria" (fornicação com a noiva Julieta antes do casamento) - inclina-se do objetivismo (aplicação da lei “às secas”) ao subjetivismo arbitrário, diante da beleza da irmã do agente (Isabela) e da proposta lançada de deitar-se com ela para que soltasse o condenado, livrando-o da pena de morte.

Transcrevem-se trechos dos diálogos entre Ângelo e Isabela, sendo que, para fins didáticos, tomar-se-ão as seguintes designações alusivas aos fundamentos lançados na decisão 
de aplicar ou não, no caso da literatura, a pena capital em face de Cláudio: Ângelo I e Ângelo

II:

\section{(Ângelo I)}

ÂNGELO - Vosso irmão se encontra sob a ação da lei; por isso, malgastais as palavras.

ISABELA - Ai de mim! Todas as almas, no passado, estavam condenadas também; mas o que tinha poder para puni-las soube dar-lhes remédio. Onde estaríeis se Ele, acaso, que é o supremo Juiz, fosse julgar-vos pelo que sois apenas? Pensai nisso, e a Clemência da bocha há de brotar-vos, como do primeiro homem.

ÂNGELO - Resignai-vos, bela menina, mas é a lei que pune vosso irmão, não sou eu. Fosse ele, embora, meu parente, irmão, filho, pouco importa: morreria amanhã.

ISABELA - Amanhã! Tão depressa! Ele não se acha preparado! Poupai-o! Até nas nossas cozinhas escolhemos a estação para matar as aves. Mostraremos ao céu menos respeito do que à nossa grosseria? Bom lorde, meu bom lorde, refleti, por favor. Quem, até hoje, morreu já por tal crime? No entretanto, muitos o cometeram.

(...)

ÂNGELO - A lei não estava morta, a lei apenas cochilava. Esses muitos não teriam praticado, sem dúvida, o delito, se o primeiro a infringi-la houvesse logo expiado a culpa. Agora está acordada, observa quando passa e, qual profeta, vê num espelho os crimes do futuro, quer novos, quer gerados por desleixo. $\mathrm{E}$ assim, quase no ponto de crescerem, não deixam sucessores, mas esfazem-se antes de terem vida.

ISABELA - Sem embargo, dai mostras de piedade.

ÂNGELO - É o que faço, ao dar mostrar de justiça, pois revelo piedade para aqueles que eu não conheço e que viriam, certo, a sofrer por um crime não punido, sobre ser com o culpado, apenas justo, pois expiando ele a culpa, não tem tempo de cometer mais crimes. Conformai-vos; vosso irmão morrerá; paras com as queixas.

ISABELA - Sereis, pois, o primeiro a aplicar esta sentença e ele a cumpri-la. É grande coisa ter de um gigante a força, mas é bárbaro, como gigante, usá-la.

(...)

ISABELA - Deus vos guarde!

(...)

ÂNGELO - De ti, de tua virtude, justamente. Que é isto? Que acontece? É ela a culpada? Serei eu? O tentado ou a tentadora, qual dos dois peca mais? Ah! Não é ela; não quer tentar-me; eu sim, que em pleno sol, mas no jeito da carniça corrompo a estação boa. Poderá dar-se o caso de a modéstia deturpar os sentidos mais depressa do que pode fazê-lo a leviandade? Sobrando-nos espaço, desejamos demolir o santuário para nossa abjeção aí plantar? Que coisa ignóbil! Que és agora, Ângelo, ou melhor, que fazes? Queres vê-la enfeada justamente no que a embeleza? A vida ao irmão concede; quando os juízes roubam, têm licença de roubar os ladrões. Como! Amá-la-ei, para assim, desejar vê-la de novo, de deleitar-me ouvindo-a? Estou sonhando? Ó inimigo astucioso, atrais os santos com isca de outros santos! A mais grave tentação é a que incita para o crime por amor à virtude. A prostituta, com a dupla força que a arte e a natureza lhe conferem, jamais pôde abalar-me; mas agora me sinto dominado por esta jovem pura. Até este instante, só para rir do amor era eu constante.

\section{(Ângelo II)}

ISABELA - Vim para ouvir a vossa decisão.

ÂNGELO - Quisera que a soubésseis, omitindo essa pergunta. Cláudio vai morrer. 
ISABELA - Está bem; que o céu guarde Vossa Honra.

ÂNGELO - Poderia viver - quem sabe? - tanto quanto eu ou vós. No entanto, é necessário que morra.

ISABELA - Porque vós sentenciastes?

ÂNGELO - Sim.

ISABELA - Dizei-me, por obséquio, o dia exato, para que nesse prazo, longo ou curto, fique ele em condições de salvar a alma.

ÂNGELO - Esses vícios imundos! Fora o mesmo perdoar a quem um ser já feito rouba à Natureza, e dar de mãos às rédeas da luxúria que faz cunhar a imagem do céu, quando proibida. Uma existência legítima destruir por meios falos, equivale a deitar metal em molde vedado para criar vida ilegítima.

ISABELA - Isso é certo no céu, não cá na terra.

ÂNGELO - Pensais assim? Pois vou já confundir-vos. Que preferis que a lei precisa e sábia a vosso irmão, agora, tire a vida, ou que, para salvá-lo, às impurezas voluptuosas o corpo abandonásseis, como a que ele manchou?

ISABELA - Podeis dar crédito ao que vos digo: preferira o corpo sacrificar a vir a perder a alma.

ÂNGELO - Não estou falando da alma; nossas faltas obrigatórias nunca são levadas em conta; valem só como parcelas.

ISABELA - Como dizeis?

ÂNGELO - Isto é, não o assevero, pois poderia defender o oposto do que afirmei. Dizei-me apenas isto: Eu, sendo agora a voz da lei escrita, pronuncio a sentença contra a vida de vosso irmão. Não se concebe que haja caridade na falta cometida para salvar-lhe a vida?

ISABELA - Fazei isso; chamo sobre minha a culpa toda; não é pecado algum, é caridade.

ÂNGELO - Se o salvásseis com risco da própria alma, a caridade e a falta ficariam bem compensadas.

ISABELA - Se é pecado pela vida dele impetrar, que o céu me faça carga de toda a culpa. Se pecardes por me atender, então, nas minhas preces matinais pedirei que esse pecado seja incluído nos meus, não vos ficando nada a ser computado.

ÂNGELO - Mas ouvi-me, pois não me acompanhais o pensamento; ou ignorante sois, ou, por astúcia ignorância fingis, e é meu fazê-lo.

ISABELA - Bem, que eu seja ignorante e apenas boa para reconhecer minhas fraquezas.

ÂNGELO - Quando a sabedoria se deprime, é por querer que o brilho próprio aumente, como as máscaras pretas que proclamam dez vezes mais valiosa a formosura velada, do que quando descoberta. Mas prestai atenção; para fazer-me compreender vou falar com mais rudeza: vosso irmão vai morrer.

ISABELA - Bem.

ÂNGELO - E seu delito é tal, como parece, que se encontra passível do castigo previsot pela lei.

ISABELA - Certo.

ÂNGELO - Admiti que não haja Outro recurso para salvar-lhe a vida ou qualquer outra; falo em termos gerais - a não ser este: que vós, sua própria irmã, vos encontrásseis requestada de alguém que, por motivo de sua posição, tivesse influência junto do juiz, e a vosso irmão pudesse libertar facilmente das algemas da lei que envolve a todos, e que meio terreno não houvesse de salvá-lo, exceto o de entregardes a mais rica jóia do vosso corpo a essa pessoa. Sem isso, fatal fora a morte dele. Que faríeis?

ISABELA - Por meu irmão, o que por mim faria. Se eu me sentisse acaso na iminência de morrer, aceitara como sendo rubis as marcas todas do chicote, e me despira para entrar na tumba como em um leito há muito cobiçado sem consentir que o corpo me poluíssem.

ÂNGELO - Sendo assim, vosso irmão deve morrer.

ISABELA - É o meio mais barato, pois é melhor que o irmão morra de um lance, do que ficar morrendo eternamente a irmã, para salvá-lo. 
ÂNGELO - Não seríeis, assim, tão cruel como essa sentença que acusais?

ISABELA - Resgate ignominioso e perdão livre são coisas diferentes; a demência legítima não tem afinidades com a redenção infame.

ÂNGELO - Há alguns momentos, da lei fazíeis um tirano, vendo no ato de vosso irmão mais um desporto do que mesmo uma culpa.

ISABELA - Oh, perdoai-me, senhor! Sucede às vezes que quem quer algo esconde o pensamento. Atenuo o que odeio, em benefício da pessoa a que amo ternamente.

ÂNGELO - Nós somos todos frágeis.

ISABELA - Pois que morra meu irmão se ele, apenas, sem ter cúmplice, for dono e herdeiro dessa tua fraqueza.

ÂNGELO - As mulheres são frágeis como os homens.

ISABELA - Sim, como seus espelhos, que tão pronto refletem formas, como se espedaçam. Oh, as mulheres! Deus as guarde! Os homens, delas se aproveitando, estragam tudo quanto eles mesmos criaram. Sim, chamai-nos dez vezes frágeis, porque somos brandas como a cute que temos e sensíveis às falas impressões.

ÂNGELO - De grado o creio. Firmado, então, no próprio testemunho do vosso sexo - pois só somos fortes, penso, ao ponto de sermos abalados pelos deslizes - vou ser corajoso: pego-vos na palavra: sede apenas o que sois, a saber: mulher. Se fordes mais, não sereis nenhuma. Mas se o sois, como vosso exterior assaz o indica, demonstrai-o nesta hora, revestindo-vos do trajo competente.

ISABELA - Só disponho de uma língua, senhor; instante peço-vos que volteis a falar na outra linguagem.

ÂNGELO - Direi, pois, sem ambas, que vos amo.

ISABELA - Meu mano amou Julieta, e me dissestes que por isso ele morre.

ÂNGELO - Não morrerá, Isabel, se amor me derdes.

ISABELA - Sei que vossa virtude o privilégio goza de uma licença com que feia se torna, só com o fim de a outros tentar.

ÂNGELO - Palavra de honra, crede-me: o que digo é todo o meu intento.

ISABELA - (...) A quem me queixarei? Quem há de crer-me, quando eu contar tudo isto? Oh bocas cheias de perigos, que, com uma língua apenas, tanto podem matar como dar vida, dobrando a lei com tais e tais caprichos, que o justo e o injusto espetam no apetite que os maneja à vontade! Vou ver Cláudio; conquanto a instigação do sangue o tenha feito cair, abriga tal espírito de honra, que se possuísse dez cabeças para estender nos cepos sanguinosos, sacrificá-las-ia antes que o corpo sua irmã abandonasse a tão abjeta profanação. Morre, meu irmão! Isabel, sê sempre pura! Os irmãos passam, a pureza dura. Mas vou contar-lhe o que Ângelo me disse para que a morte aceita com ledice ${ }^{1}$.

A modernidade iluminista teve espaço significativo, diante da busca incessante da razão e da certeza - o "cogito" (Descartes) -, de maneira que a subjetividade acabou por assujeitar o objeto da relação, instrumentalizando-o de tal modo a vingar um solipsismo. Dito de outro modo, o sujeito solipsista é o indivíduo egoísta, que não compartilha das expectativas comunitárias e, na atualidade, é revestido da crença do "decido conforme a minha consciência” (Streck).

A ideia de paradigma foi desenvolvida por Thomas Kuhn, no âmbito das ciências da natureza, desenvolvida, entre outros autores, por Ernildo Stein no âmbito da filosofia. Já a

\footnotetext{
1 SHAKESPEARE, William. Medida por Medida. Ed. Ridendo Castigat Mores. Disponível em: <www.jahr.org>. Acesso em 5 de agosto de 2015.
} 
concepção de quadro referencial teórico é defendida por Lorenz Puntel, para o qual a existência de um alicerce teórico é de fundamental relevo para a investigação científica. Conforme já destacado, o referencial teórico adotado consiste na fenomenologia hermenêutica (filosofia hermenêutica e da hermenêutica filosófica - Heidegger/Gadamer) e no Direito como Integridade (Dworkin), na senda trilhada pela Crítica Hermenêutica do Direito (Streck), tomando-se como pano de fundo as imbricações entre o Direito e a Literatura, a partir da obra "Medida por Medida", de Shakespeare.

Com efeito, a reviravolta linguística (linguist turn) demonstra que não se pode filosofar sem a linguagem, tese sobre a qual se concentra o pensamento filosófico do século XX, haja vista que esta é o "momento necessário constitutivo de todo e qualquer saber humano, de tal modo que a formulação de conhecimentos intersubjetivamente válidos exige reflexão sobre sua infra-estrutura lingüística". A seu turno, a pragmática existencial e a reviravolta hermenêutico-transcendental, no eixo Heidegger-Gadamer lançam suas bases sobre o ser e o compreender, passando a linguagem a ser um elemento imprescindível e co-constitutivo do processo reflexivo $^{2}$.

Nessa senda, a filosofia hermenêutica (Heidegger) e a hermenêutica filosófica (Gadamer), na perspectiva dos direitos fundamentais, buscam, na intersubjetividade, uma necessária alteridade tendo em vista a relação sujeito-sujeito. Dito de outro modo, o sujeito não mais é assujeitado pelo objeto, tampouco assujeita este, mas sim, o ser é destacado na relação com os entes, por intermédio do dasein (ser-aí).

\section{POSITIVISMO JURÍDICO, SOLIPSISMO E DISCRICIONARIEDADE JUDICIAL. “MODELOS DE FUNDAMENTAÇÃO”: ÂNGELO I OU II?}

Tome-se o caso concreto referente ao genro que mata o sogro, restando condenado por sentença criminal transitada em julgado, tendo a esposa ajuizado demanda declaratória de exclusão de partilha do divórcio, em face do marido, porquanto casados pelo regime da comunhão universal de bens ${ }^{3}$.

\footnotetext{
2 Nesse sentido, ver OLIVEIRA, Manfredo Araújo de. Reviravolta linguístico-pragmática na filosofia contemporânea. 3. ed. São Paulo: Loyola, 2006, pp. 13, 201 e 225 e ss.

3 Apelação Cível n. ${ }^{0}$ 70005798004, Sétima Câmara Cível do Tribunal de Justiça do Rio Grande do Sul, Relator Desembargador Luiz Felipe Brasil Santos, j. 9-4- 2003. Disponível em: <http://www.tjrs.jus.br>. Acesso em 5 de agosto de 2015.
} 
A questão pode ser formulada nos seguintes termos: $O$ genro que mata o sogro tem direito à meação da herança?

A ação intentada em primeiro grau foi julgada extinta em face da coisa julgada, tendo a autora interposto recurso de apelação, o qual foi provido para desconstituir a sentença. Em novo pronunciamento, o juízo a quo julgou improcedente o pedido deduzido pela autora.

Em sede de apelação, sustentou a apelante os seguintes argumentos 1) o apelado foi condenado por homicídio qualificado (motivo torpe) de seu sogro, pai da apelante, devendo, por isso, ser excluído da partilha de bens do divórcio, eis que o patrimônio lá dividido é oriundo, exclusivamente, do inventário do de cujus; (2) por não haver previsão legal, deve ser utilizada a analogia a fim de integrar a norma jurídica, no presente caso; (3) para suprir tal lacuna, deve incidir o art. 1595, inc.I, do Código Civil, bem como a jurisprudência e o direito internacional.

O Desembargador Relator desproveu o apelo, entendendo que não há respaldo legal para a tese da analogia suscitada pela apelante, diante das hipóteses taxativas de exclusão por indignidade, as quais recaem sobre aqueles que "tentaram ou participaram de tentativa contra a vida daqueles de cuja sucessão se tratar".

A Desembargadora Presidenta abriu a divergência, sustentando que fere a moral comum que o apelado se beneficie da sua conduta, aderindo à corrente do "Direito Alternativo", provendo o recurso de apelação.

Já o Desembargador Vogal encaminhou voto em idêntico sentido, dando provimento ao apelo diante da possibilidade de criação judicial de mais uma hipótese de exclusão da indignidade.

A resposta lançada pelo Tribunal de Justiça pode ser considerada válida à luz do Direito?

O percurso argumentativo é de fundamental importância para o intérprete, de modo que a resposta correta ou constitucionalmente adequada deve estar alicerçada em argumentos de princípio e não de política ou de moral (Dworkin), sob pena de fragilizar-se a autonomia do direito.

Isso porque o direito não se confunde com a moral, tampouco a moral assume um papel corretivo daquele; ambos são cooriginários (Habermas/Streck), ou seja, a sua comum origem faz com que a institucionalização da moral no direito por intermédio dos princípios leve o intérprete a "fechar" a interpretação, conforme destacam Lenio Streck e Luigi Ferrajoli. 
É possível sustentar a premissa segundo a qual os votos dos Desembargadores estão centrados em versões do positivismo jurídico, quais sejam, o positivismo exegético (modelo de juiz “Ângelo I"), o positivismo axiológico e o positivismo fático ou realismo jurídico (modelo de juiz “Ângelo II”).

Nesse sentido, o Desembargador Relator fundamenta sua decisão no positivismo exegético, sustentando que "o fundamento da apelante para ver seu ex-marido excluído da partilha na ação de divórcio (processo $\mathrm{n}^{\circ} 11488$ - autos em apenso), não encontra respaldo legal, eis que pretende aplicar, por analogia, o art. 1595, inc. I, do CC”. Destacou, ainda, que "A legislação ora sob foco traz uma sanção - exclusão da herança - aos que tentaram ou participaram de tentativa contra a vida daqueles de cuja sucessão se tratar”, e que o objetivo da lei foi no sentido de que "a regra da indignidade recaísse tão-só naqueles possuidores de laços de sangue e/ou de extrema afeição com o autor da herança, a ponto de serem penalizados por atos atentatórios a sua vida, honra ou liberdade".

Já a Desembargadora Presidenta tem como ponto de apoio o positivismo axiológico, admitindo claramente a fragilização da autonomia do Direito em função da moral, a qual assume um papel corretivo e externo. A argumentação pauta-se, ainda, na corrente do Direito Alternativo, a qual se justificava na fase anterior à Constituição de 1988, sobretudo em virtude da restrição de direitos fundamentais promovida pelo regime militar brasileiro. Todavia, a partir da $\mathrm{CF} / 88$, o discurso jurídico deve voltar as suas baterias para a consolidação da "legalidade constitucional" (Elías Díaz/Lenio Streck). Vale trazer a lume alguns trechos do voto da Desembargadora:

(...) se há omissões na identificação das pessoas integrantes do suporte fático, de tal omissão não se ressentem os princípios, que devem sempre ser identificados para serem invocados quando se verifica uma lacuna na lei. Assim, se há omissão de norma legal, deve sempre que prevalecer o princípio consagrado pelo legislador que, indiscutivelmente, é o de não permitir a quem atenta contra a vida de outrem possa dele receber alguma coisa, seja como sucessor, seja como cônjuge ou companheiro do sucessor, Essa é a intenção do legislador e a função da Justiça é exatamente fazer incidir a orientação ditada pela lei. Aliás, para isso é que somos juízes, para fazer justiça segundo os princípios que regem o sistema jurídico. Não somos, como dizia Montesquieu: la bouche de la loi, juízes que simplesmente se limitam a repetir e aplicar a norma contida no elenco legal, permitindo que se conviva com a injustiça. Somos Juízes de Direito, integramos um Tribunal de Justiça.

Confesso que fere meu senso de justiça fazer uma injustiça dessa ordem. No dia em que tomei posse como magistrada, jurei fazer justiça, não aplicar a lei de forma mecânica e casuísta. Se para isso, quem sabe, tiver que afrontar a lei, a dar ensejo talvez de ser acusada de ter me tornado adepto da nominada "justiça alternativa", paciência. Se for esse a qualificativo que mereço, vou aceitar, mas não posso permitir é o locupletamento de alguém com a própria torpeza. 
Por seu turno, o Desembargador Vogal alicerça sua decisão em uma espécie de positivismo fático ou realismo jurídico, aceitando, inclusive, a tese segundo a qual pode o juiz criar nova hipótese legal de exclusão da herança por indignidade. Recorre aos "princípios gerais de Direito" para sustentar, a partir do voto da Desembargadora Presidenta, uma criação judicial do Direito. A esse respeito, argumenta que

\begin{abstract}
Parto da análise que foi feita pela eminente Desa. Maria Berenice, da Lei de Introdução, que diz, no conhecidíssimo art. $4^{\circ}$, que, quando a lei for omissa, o Juiz decidirá o caso de acordo com a analogia, os costumes e os princípios gerais do Direito e atenderá, como proclama o art. $5^{\circ}$, os fins sociais e as exigências do bem comum.

Uma das características de todos os diplomas materiais - e foi também o caso do código em vigor - é a preservação do sentido ético das suas regras. No código, como foi acentuado por todos os comentadores e por aqueles que vinham acompanhando toda a discussão do atual Código Civil, é o princípio ético que prevalece, como por exemplo, no caso dos contratos, o princípio da boa-fé.

Não há por que, lá como aqui, deixar-se de divisar, no caso concreto, a aplicação do princípio ético, do princípio do senso comum, do princípio da equidade, ancorado nos princípios gerais do Direito, já que a aplicação da analogia é dificultada, podendo-se utilizar os princípios do Direito e dos costumes.

Então, é o sentido que adoto, aceitando a tese sustentada da tribuna de que o meeiro não deixa de ser um legatário ex legis; portanto, aplicando-se também a indignidade no caso da sucessão legítima, pode-se construir uma nova hipótese de que ali se incluem também outras pessoas que, aproveitando-se diretamente do resultado do seu inexplicável gesto, venham a matar os autores da herança.
\end{abstract}

A questão acerca de como os juízes decidem os casos, tratada por Dworkin em sua construção teórica integrativa, leva em conta alguns critérios, tais como a coerência e a integridade, comparando o direito como uma espécie de romance em cadeia (chain novel), no qual o juiz deve levar em conta os precedentes dos juízes que já se pronunciaram, a lei, o direito, e dar prosseguimento, como se fosse o escritor de um romance.

Dworkin $^{4}$ tece criticas às correntes doutrinárias do convencionalismo e do pragmatismo, apontando suas insuficiências na construção de uma teoria do direito. Na perspectiva do convencionalismo, o direito é aquilo que realmente é, e não o que os juízes pensam ser. Referida corrente faz o direito depender de convenções sociais distintas, designadas convenções jurídicas, ou seja, de convenções sobre quais instituições deveriam ter o poder de elaboração das leis e de que maneira. Já o pragmatismo baseia-se na negativa de que as pessoas tenham quaisquer direitos, contrapondo os direitos das pessoas àquilo que seria pior para a comunidade, ou seja, em face dos interesses da maioria, apenas porque uma legislação estabeleceu, ou porque juízes decidiram que outras pessoas teriam tal direito. O

\footnotetext{
${ }^{4}$ DWORKIN, Ronald. O Império do Direito. Trad. Jefferson Luiz Camargo. 2. ed. São Paulo: Martins Fontes, 2007, p.pp. 141-2; 186.
} 
principal defensor do pragmatismo, na atualidade, é Richard Posner ${ }^{5}$, juiz nos Estados Unidos e o propulsor da corrente direito e economia. O pragmatismo aceita que uma decisão seja razoável à luz dos interesses conflitantes no caso em questão, ainda que uma decisão razoável não seja necessariamente uma decisão "correta"6.

A seu turno, a coerência pressupõe a análise ampla do direito e a sua reconstrução histórico-institucional, de modo que os casos futuros tenham um tratamento semelhante aos casos enfrentados pelos juízes, dentro da cadeia interpretativa. É uma relação de conexão entre a decisão judicial e o próprio direito.

Para além da coerência, a integridade obriga que os juízes levem em conta os princípios tais como a justiça, a equanimidade ou o "jogo limpo" (fairness), o devido processo legal para a tomada de decisão, a qual, além de ser coerente com a sua história institucional, deve ser justa. Além disso, deve o juiz observar a comunidade de princípios, de modo a afastar um indesejável subjetivismo no ato de julgar.

Já a perspectiva do romance em cadeira (chain novel) compara o juiz a uma espécie de romancista, que deve dar prosseguimento a uma obra coletiva, razão pela qual não pode desprezar o contributo dos juízes que o antecederam, na análise dos precedentes, da lei e do Direito.

Nesse ponto, lembra Eros Grau ${ }^{7}$ que o direito é alográfico, ressaltando a diferença entre texto e norma, entre o autor e o intérprete.

Outro traço do positivismo é a desvinculação entre o direito - mais precisamente, a ciência do direito - e a moral, compreendidos com espaços independentes e sem qualquer conexão, nomeadamente em virtude das lições de Hans Kelsen. Há, em síntese, quatro teses sobre a relação entre o direito e a $\operatorname{moral}^{8}$ : a) Vinculação (jusnaturalismo); b) Separação (positivismo jurídico - Kelsen, Hart, Ferrajoli, entre outros); c) Complementaridade (Alexy ${ }^{9}$ );

\footnotetext{
5 O referido autor se posiciona em favor de um "ceticismo moral pragmático", contrapondo-se àquilo que denomina de "moralismo acadêmico", destacando que "a moral é um fenômeno local, ou seja, não existem universais morais interessantes”. POSNER, Richard A. A problemática da teoria moral e jurídica. Trad. Marcelo Brandão Cipolla São Paulo: Martins Fontes, 2012, pp. 6-11.

${ }^{6}$ POSNER, Richard A. Como deciden los jueces. Trad. Victoria Roca Pérez. Madrid: Marcial Pons, 2011, pp. 278-9.

${ }^{7}$ GRAU, Eros. Ensaio e discurso sobre a interpretação/aplicação do Direito. 4. ed. São Paulo: Malheiros, 2006, pp. 82-3.

${ }^{8}$ Cf. STRECK, Lenio Luiz. "Direito”. Dicionário de Filosofia Política. São Leopoldo: Editora Unisinos, 2010, pp. 147-8.

9 ALEXY, Robert. Conceito e Validade do Direito. Trad. Gercélia Batista de Oliveira Mendes. São Paulo: Martins Fontes, 2009, em especial pp. 151-2, onde o autor refere que o Direito formula uma "pretensão à correção".
} 
d) Co-originariedade (Dworkin, Habermas e Streck): Institucionalização da moral no direito e não uma "pretensão corretiva".

A tese da separação entre o direito e a moral, sustentada pelo positivismo, não encontra ressonância no constitucionalismo contemporâneo, haja vista que a moral e o direito são co-originários, isto é, trata-se da institucionalização da moral no direito (DworkinHabermas). Não há cisão estrutural entre direito e moral. Vale dizer que não se está falando da moral individual, mas da moralidade política ou da moral crítica, isto é, um a priori compartilhado. Por isso que os princípios "fecham" a interpretação ao invés de abri-la (Streck).

O Direito deve ser interpretado com coerência e integridade, a partir da concepção da “unidade do valor". É preciso conferir autonomia ao Direito de modo a evitar que argumentos de política ou de moral possam fragilizá-lo, máxime na atual quadra, caracterizada pelo fato de que a sociedade parou de se questionar (Castoriadis). A coerência é uma valiosa ferramenta contra a discriminação, ao passo que a integridade no Direito impõe à jurisdição que trate as pessoas com igual consideração e respeito.

Há, pois, uma responsabilidade política da jurisdição, na linha de Dworkin, na consecução dos direitos humanos e fundamentais. Isso porquanto a reconstrução da história institucional do Direito não pode ficar refém de esquemas subsuntivos, sob pena de cair no “aguilhão semântico" (Dworkin), em um gradual "descolamento" entre o texto e a norma e, por óbvio, com a faticidade dos acontecimentos sociais.

O problema do positivismo normativista não é mais o "juiz boca da lei" (Montesquieu), mas sim, como se decidem os casos, isto é, como se controla o poder discricionário dos juízes. Como salienta Losano ${ }^{10}$, o século XX põe em discussão o idealismo kantiano e a fé na racionalidade, pontos de apoio da teoria pura do Direito de Kelsen. No Direito, contesta-se a lógica como principal instrumento da interpretação, privilegiando-se a vontade do juiz em relação à dedução lógico-formal. A questão na qual Kelsen, ao edificar sua teoria pura, deixa em aberto é justamente a interpretação do Direito, vista como ato de

\footnotetext{
${ }^{10}$ LOSANO, Mário. Sistema e estrutura do Direito: O século XX. Trad. Luca Lamberti. São Paulo: Martins Fontes, volume 2, 2010, p. 135. Kelsen, em sua Teoria Pura, procura realizar uma depuração do mundo real. Como explica Losano, "a validade do direito positivo é explicada mediante uma estrutura piramidal (a graus, hierárquica), na qual as normas de nível inferior recebem sua validade das superiores. A norma positiva mais elevada é a constituição, que recebe sua validade da norma fundamental; e esse é o elemento mais controvertido da doutrina inteira. Kelsen a define, de fato, como „uma norma não posta, mas pressuposta ${ }^{\text {ee }}$, como expressão de um ato de vontade fictício; como pressuposto lógico-transcendental do sistema inteiro”. LOSANO, Mário. Op. cit., p. 51.
} 
conhecimento e como ato de vontade, processo mediante o qual o juiz, em sua concepção, seria livre para interpretar, dentro da moldura da norma jurídica ${ }^{11}$.

A discricionariedade é uma das características centrais da corrente do positivismo jurídico. Kelsen acentuava que a interpretação era um problema de política jurídica, no oitavo capítulo, criando a denominada "moldura da norma" como espaço decisório válido. Isso porquanto sua preocupação não era com o Direito, mas sim, com a Ciência do Direito, motivo pelo qual a crítica doutrinária à sua construção teoria recaiu justamente sobre o risco do decisionismo e do voluntarismo do aplicador da norma ${ }^{12}$.

$\mathrm{O}$ conceito de discricionariedade ${ }^{13}$ é um dos mais plurissignificativos e difíceis da teoria do Direito, conforme reconheceu Engisch.

\footnotetext{
${ }^{11}$ Nessa linha de entendimento, Kelsen sublinha que a "fixação de normas jurídicas individuais é a função específica dos tribunais. Ao esses decidirem um caso concreto em aplicação de uma norma jurídica geral, é sua decisão uma norma jurídica individual: a individualização ou concretização da norma jurídica geral aplicada. Mas também quando eles - para isso autorizados - decidem segundo poder discricionário completamente livre, tem sua decisão o caráter de uma norma jurídica individual, se eles, agora, decidem que - afinal de contas - um ato de coerção deve realizar-se. (...) Por isso, a fórmula conhecida do jurista americano e antigo membro do tribunal supremo, Oliver Wendell Holmes: „As profecias do que as cortes farão de fato, e nada mais pretencioso, são o que eu entendo por direito". Isso também se aplica para a tese de um outro teórico do direito americano, John Chipman Gray: „Todo o direito é direito produzido por juiz"e". KELSEN, Hans. "O que é positivismo jurídico?". Direito Natural, Direito Positivo, Direito Discursivo. Alexander Hollerbach et al.; Luís Afonso Heck (org. e trad.). Porto Alegre: Livraria do Advogado, 2010, p. 88 (pp. 85-94).

${ }^{12}$ Kelsen prende-se à vontade do órgão aplicador, referindo que este é "um criador de Direito e também ele é, nesta função relativamente livre. Justamente por isso, a obtenção da norma individual no processo de aplicação da lei é, na medida em que nesse processo seja preenchida a moldura da norma geral, uma função voluntária". Percebe-se, pois, que pende de solução o problema do decisionismo judicial na obra de Kelsen, cuja crítica é essencial à produção democrática do Direito. KELSEN, Hans. Teoria Pura do Direito. Trad. João Baptista Machado. São Paulo: Martins Fontes, 2011, p. 393. Em uma leitura crítica, Larenz afirma que "quando KELSEN, para se manter longe de tais juízos de valor, declara que a ciência do Direito é incapaz de atingir, através da "interpretação" de uma norma, juízos ",correctos", ,deita a criança fora com a água do banho"', Destaca, também, que Kelsen não reconhece "qualquer diferença entre legislação, jurisprudência, atividade administrativa e actuação da „autonomia privada". Trata-se sempre para ele de estabelecer uma norma hierarquicamente inferior no quadro de uma norma hierarquicamente superior. O que é, decerto, uma concepção sedutora na sua simplicidade, mas de forma alguma uma concepção que corresponda às diferenças realmente existentes. Ela limita a interpretação jurídica à mera interpretação verbal, à indicação das significações possíveis, de acordo com o sentido das palavras, de entre as quais tem o aplicador da norma de escolher. Fica à sua disposição o modo de escolha. Esta concepção é dificilmente compatível com a função da judicatura no Estado constitucional. Não lhe faltam, pois, vozes críticas. LARENZ, Karl. Metodologia da Ciência do Direito. 5. ed. Trad. José Lamego. Lisboa: Fundação Calouste Gulbenkian, 2009, pp. 107-108. (grifo nosso)

${ }^{13}$ Sobre o conceito de discricionariedade, Engisch afirma que é "um dos conceitos mais plurissignificativos e mais difíceis da teoria do Direito. As dificuldades adquirem uma particular premência e um peso particular pelo facto de a teoria da discricionariedade se ter tornado ao mesmo tempo um ponto fulcral do Direito processual". Partindo da imagem do "espaço livre", o autor refere "a possibilidade de escolher entre várias alternativas diferentes de decisão, quer o espaço livre esteja apenas entre duas decisões contraditoriamente opostas (...) ou entre várias decisões à escolha numa relação disjuntiva", destacando, enfim, que "é o direito, quase sempre a lei, que numa parte da norma abre a possibilidade de uma escolha entre várias alternativas de facto possíveis" ENGISCH, Karl. Introdução ao Pensamento Jurídico. Trad. João Baptista Machado. 10 ed. Lisboa: Fundação Calouste Gulbenkian, 2008, pp. 214-219. Diferente de Engisch que defende o poder discricionário judicial, Dworkin nega a discricionariedade (em sentido forte), na perspectiva do Direito como integridade e sustentando a existência de respostas corretas, ou seja, adequadas à Constituição. Ver DWORKIN, Ronald. Levando os direitos a sério. Trad. Nelson Boeira. Martins Fontes, 2002, p. 56 e ss. No contexto dos países da tradição da Common Law, Merryman afirma que "os juízes podem exercer a discricionariedade, mas eles também devem
} 
O problema em torno da discricionariedade judicial é a pedra de toque do debate entre Hart e Dworkin, o que motivou uma série de artigos por parte deste, transformados em livros como Taking Rights Seriously e A Matter of Principle. Em um positivismo "moderado", Herbert Hart, em sua obra $O$ Conceito de Direito, afirmava que, nos casos difíceis, envoltos em uma "zona de penumbra", o juiz tem liberdade para a escolha da solução, valendo-se do poder discricionário, no âmbito das decisões interpretativas.

A discricionariedade tem dois sentidos "fracos" e um sentido considerado "forte", o qual é o objeto do estudo de Dworkin, sendo que, na resolução dos casos "difíceis", criou a figura do juiz "Hércules", com poderes sobre-humanos, com capacidades especiais para a resolução de tais casos. "Hércules", na verdade, é uma metáfora (Streck) ou uma ficção (Kaufmann $)^{14}$, figura que não pode ser lida de forma solipsista, sob pena de corromper a própria teoria de Dworkin. Dworkin, então, nega a discricionariedade (em sentido forte), na perspectiva do Direito como integridade e sustentando a existência de respostas corretas, ou seja, adequadas à Constituição ${ }^{15}$.

$\mathrm{Na}$ aplicação do direito propugnada pelo realismo jurídico, a decisão do caso concreto não depende das racionais leis da lógica, mas da vontade do juiz, passando-se do formalismo ao antiformalismo, sendo que o juiz decidia "segundo o seu convencimento, que podia

\footnotetext{
suportar maior ônus em sua responsabilidade em relação à certeza e estabilidade do direito". MERRYMAN, John Henry; PÉREZ-PERDOMO, Rogelio. A Tradição da Civil Law. Uma introdução aos Sistemas Jurídicos da Europa e da América Latina. Trad. Cássio Casagrande. Porto Alegre: Sergio Antonio Fabris Editor, 2009, p. 86. Afirma Streck que a discricionariedade judicial, diferentemente da esfera administrativa, envolve as decisões interpretativas, de tal maneira que "há aqui uma nítida diferença de situações: no âmbito judicial, o termo „discricionariedade" refere-se a um espaço a partir do qual o julgador estaria legitimado a criar a solução adequada para o caso que lhe foi apresentado para julgamento. No caso do administrador, tem-se por referência a de um ato autorizado por lei e que, por esse motivo, mantém-se adstrito ao princípio da legalidade. STRECK, Lenio Luiz. Verdade e Consenso. Constituição, Hermenêutica e Teorias Discursivas. 4. ed. São Paulo: Saraiva,

2012, p. 40. Streck afirma, ainda, que não há uma fronteira clara entre arbitrariedade e discricionariedade, denunciando que "Arbitrariedade e/ou discricionariedade de sentidos (ou nos sentidos) são „práticas típicas de um racionalismo que teima em sobreviver em outro paradigma" e que a "discricionariedade pregada e defendida pela maior parte da teoria do direito - em especial as teorias procedurais-argumentativas - é exatamente a que se confunde com a arbitrariedade. Nelas, o afastamento da arbitrariedade é argumento e álibi teórico para a justificação da discricionariedade (retome-se, sempre, admissão da „necessidade da discricionariedade" para que o intérprete possa ponderar, conforme defendem Robert Alexy e Prieto Sanchís, para falar apenas nestes). Este é o ponto. A discricionariedade que combato é a do sub-jectum, que dis-põe dos sentidos do direito, como se fosse „proprietário dos sentidos" e dos „meios-de-produção-dos-sentidos", circunstância que a aproxima das teses pragmatistas em geral, em que o caso concreto é transformado em álibi para voluntarismos, a partir de um ,grau zero de significado"'. STRECK, Lenio Luiz. O que é isto - decido conforme minha consciência? 4. ed. rev. Porto Alegre: Livraria do Advogado, 2013, pp. 68-69.
}

${ }^{14}$ Segundo Kaufmann, Dworkin está ciente de que para a determinação da única solução correta, tem de pressupor um jurista com capacidades sobre-humanas (Hércules), para quem não há espaço para escolha livre, discricionariedade, sendo que Hércules "é evidentemente uma ficção, mas Dworkin exige que o juiz no exercício da sua faculdade de julgar tome em consideração os ,general principles", pelo menos, para o esclarecimento das "zonas de penumbra'",' KAUFMANN, Arthur. Filosofia do Direito. Op. cit., p. 77.

${ }^{15}$ Ver DWORKIN, Ronald. Levando os direitos a sério. Trad. Nelson Boeira. Martins Fontes, 2002, p. 56 e ss. 
também não coincidir com a ratio do legislador. A relação entre o legislador e o juiz resultava não apenas alterada, mas invertida: o juiz podia comportar-se como se fosse o legislador"16.

No Movimento do Direito Livre, cujo expoente foi Hermann Kantorowicz, o objetivo consistiu na contraposição entre a "rigidez da certeza do direito, muitas vezes sufocante, e a flexibilidade da decisão individual, muitas vezes imprevisível”. Por outro lado, com o advento do nacional-socialismo, a teoria era utilizada "para desvincular os juízes do respeito à lei e para obter, assim, uma jurisprudência de partido" $"$.

O debate em torno do positivismo, como bem refere Streck, é uma discussão em torno de rupturas paradigmáticas, sendo que a característica nuclear do positivismo, qual seja, a discricionariedade, está ligada ao paradigma da subjetividade, ou seja, ao esquema sujeitoobjeto. Nessa linha, o mencionado doutrinador sustenta procurar ancorar a discussão " $n a$ evolução dos paradigmas filosóficos e a superação da filosofia da consciência pelo giro

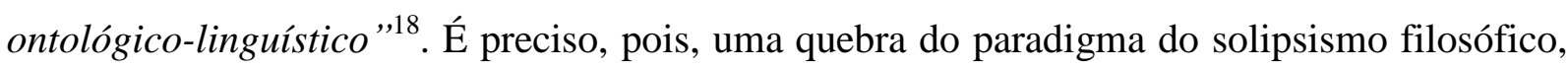
o qual anima a discricionariedade positivista, alicerçado na "consciência encapsulada que não sai de si no momento de decidir", isto é, que o "mundo serialé apenas o resultado das representações que realizamos a partir de nosso "feixe de sensações" ",19.

\section{A REVIRAVOLTA HERMENÊUTICA COMO PARADIGMA FILOSÓFICO NO DIREITO: QUE “MEDIDA" PARA A DECISÃO JUDICIAL?}

A reviravolta linguística (linguist turn) demonstra que não se pode filosofar sem a linguagem, tese sobre a qual se concentra o pensamento filosófico do século XX, haja vista

\footnotetext{
${ }^{16}$ LOSANO, Mário. Sistema e estrutura do Direito: O século XX. Trad. Luca Lamberti. São Paulo: Martins Fontes, volume 2, 2010, p. 143. O mais significativo representante do realismo americano foi Oliver W. Holmes, corrente que sustenta que "o direito se extrai da análise das sentenças. Graças a essa análise pode-se razoavelmente (não mais, assim, racionalmente!) estabelecer como se comportarão os juízes no futuro. "What I mean by the law",

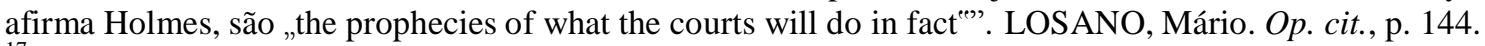

${ }^{17}$ LOSANO, Mário. Op. cit., pp. 158 e 163.

18 STRECK, Lenio Luiz. O que é isto - decido conforme minha consciência? 4. ed. Porto Alegre: Livraria do Advogado, 2013, p. 60.

${ }_{19}$ STRECK, Lenio Luiz. Op. cit., pp. 60-61. Explica o doutrinador que o sujeito solipsista está na base de afirmações do tipo "decido conforme minha consciência", configurando uma construção filosófica que tem como "ponto de partida o cogito ergo sum de Descartes, passando pelas mônadas de Leibniz, pelo eu transcendental de Kant, até chegar a seu extremo em Schopenhaeur, com a ideia de mundo como vontade e representação" STRECK, Lenio Luiz. Op. cit., pp. 60-61. Segundo Blackburn, o solipsismo consiste na "crença de que, além de nós, só existem as nossas experiências. O solipsismo é a consequência extrema de se acreditar que o conhecimento deve estar fundado em estados de experiência interiores e pessoais, e de não se conseguir encontrar uma ponte pela qual esses estados nos dêem a conhecer alguma coisa que esteja além deles. O solipsismo do momento presente estende este ceticismo aos nossos próprios estados passados, de tal modo que tudo o que resta é o eu presente". BLACKBURN, Simon. Dicionário Oxford de Filosofia. Trad. Trad. Desidério Murcho et al. Rio de Janeiro: Zahar, 1997, p. 367.
} 
que esta é o "momento necessário constitutivo de todo e qualquer saber humano, de tal modo que a formulação de conhecimentos intersubjetivamente válidos exige reflexão sobre sua infra-estrutura lingüística". Em suas Investigações Filosóficas, Wittgenstein, em uma ruptura com paradigma estritamente lógico do discurso, desenvolvido no Tratado LógicoFilosófico, insere a linguagem dentro do contexto vivencial, ou seja, dos jogos de linguagem, de tal modo a referida expressão "deve salientar aqui que falar uma língua é parte de uma atividade ou de uma forma de vida" ${ }^{, 20}$. Na sequência, a pragmática existencial e a reviravolta hermenêuticotranscendental, no eixo Heidegger-Gadamer lançam suas bases sobre o ser e o compreender, passando a linguagem a ser um elemento imprescindível e co-constitutivo do processo reflexivo $^{21}$.

Nessa senda, a filosofia hermenêutica (Heidegger) e a hermenêutica filosófica (Gadamer), na perspectiva dos direitos fundamentais, buscam, na intersubjetividade, uma necessária alteridade tendo em vista a relação sujeito-sujeito ${ }^{22}$. Dito de outro modo, o sujeito não mais é assujeitado pelo objeto, tampouco assujeita este, mas sim, o ser é destacado na relação com os entes, por intermédio do dasein (ser-aí) ${ }^{23}$.

${ }^{20}$ WITTGENSTEIN, Ludwig. Investigações Filosóficas. Trad. Marcos G. Montanoli. 7. ed. Petrópolis: Vozes: Bragança Paulista: Editora Universitária São Francisco, 2012, p. 27. Refere o autor que a "importância de tais possibilidades de transformação, por exemplo, de todas as frases afirmativas em frases que se iniciam com a cláusula „Eu penso" ou „Eu creio" (portanto, digamos, em descrições de minha vida interior) vai-se mostrar mais claramente em um outro lugar. (Solipsismo.)". WITTGENSTEIN, Ludwig. Op. cit., p. 28.

21 Nesse sentido, ver OLIVEIRA, Manfredo Araújo de. Reviravolta linguístico-pragmática na filosofia contemporânea. 3. Ed. São Paulo: Loyola, 2006, pp. 13, 201 e 225 e ss.

${ }^{22}$ Como ensina Stein, em torno da questão dos paradigmas, a modernidade chegou ao fim e que a "subjetividade entrou em crise e porque progressivamente foram surgindo hipóteses de que o fundamento último do conhecimento não é o sujeito finito, mas o mundo prático. Que o fundamento último do conhecimento, portanto, reside no nosso convívio com as coisas, os instrumentos e as pessoas". O ponto fundamental é que as ciências humanas em geral "não vão ter mais como fundamento o sujeito que se afirma de alguma maneira". O novo paradigma é um "estilo de pensar, onde existe um modelo teórico, um método, uma teoria da verdade, uma teoria da racionalidade. Enfim, os critérios últimos da verdade não serão mais fundamentos absolutos, nem será mais também o sujeito absoluto. Mas os critérios últimos da verdade serão simplesmente momentos que podemos explicitar deste mundo vivido e deste mundo prático. Não temos outros princípios a partir de onde estabelecer nem Deus, nem o mundo das ideias, nem o eu penso kantiano, nem o saber absoluto de Hegel - mas, de certo modo é desde o mundo prático que temos que extrair critérios de verdade. Critérios de verdade implicam buscar condições de possibilidade da verdade. Estas condições de possibilidade da verdade, as condições transcendentais da verdade, que antes eram ditas como sendo do sujeito e da subjetividade, agora são extraídas do mundo prático. Então cada um dará as condições de possibilidade da verdade, na ciência, na filosofia, desde o mundo prático, desde o mundo comum vivido. É ali que temos a finitude dada concretamente". STEIN, Ernildo. Epistemologia e Crítica da Modernidade. 3. ed. Ijuí. Ed. Unijuí, 2001, pp. 42-43.

${ }^{23}$ Como afirma Stein, a "questão da diferença ontológica, que será progressivamente o tema central da filosofia heideggeriana, deve ser visualizada em sua vinculação com a circularidade do ser-aí (....). À medida que o ser-aí é onticamente ontológico, à medida que „ao ser-aí pertence compreensão do ser", à medida que „no homem impera um pertencer ao ser", à medida que „o ser apenas se manifesta fenomenologicamente e dura enquanto, através de seu apelo, se endereça ao homem", afirmamos que a diferença ontológica acontece na faticidade circular do ser- 
Os dois teoremas fundamentais da hermenêutica são o círculo hermenêutico e a diferença ontológica. O círculo diz respeito ao movimento do interpretar no já compreendido, não sendo vicioso, mas sim virtuoso, isto é, “O decisivo não é sair do círculo mas entrar no círculo de modo adequado. Esse círculo do compreender não é um cerco em que se movimenta qualquer tipo de conhecimento. Ele exprime a estrutura prévia existencial, própria da presença". Aduz Heidegger, ainda, que "Na elaboração da posição prévia, da visão prévia e concepção prévia, ela deve assegurar o tema científico a partir das coisas elas mesmas"24.

Por seu turno, a diferença ontológica radica na relação entre o ser e o ente, nos planos ôntico e ontológico, sendo que, enquanto o ente é mundano, o ser é transcendental, na esteira do giro ontológico-linguístico decorrente da superação da filosofia da consciência.

O discurso do apego ao método colima o ponto nevrálgico da subjetividade, promovendo o "esquecimento do ser" (Heidegger) e a prévia antecipação de sentido provocada pelo dasein, comparável a uma clareira na escuridão, ou seja, há um desvelamento e um velamento do ser que se revela nos entes. O a priori compartilhado, as pré- compreensões, os pré-juízos - e prejuízos - que brotam do compartilhamento de experiências mundivivenciais do ser humano como ente de relação, colocam em xeque o método como instrumento hábil para se alcançar a verdade. É por isso, para alguns autores, a obra Verdade $e$

Método (Gadamer) merece compreensão como Verdade contra o Método ${ }^{25}$.

Noutras palavras, o método, com sua pretensão de abarcar e sistematizar a realidade, sempre deixa escapar algo, e, não bastasse isso, chega tarde na resolução dos conflitos, justamente porque, ao interpretarmos, já compreendemos. Heidegger ${ }^{26}$ destaca que a interpretação de algo como algo funda-se em uma posição prévia, visão prévia e concepção prévia. Na mesma linha, interpretamos porque compreendemos e não compreendemos porque interpretamos, não se tratando de mero jogo de palavras, mas sim, a presença do ser-aí no processo de produção de sentido, nomeadamente na esfera jurídica, havendo, pois, uma fusão

aí. A diferença ontológica revelar-se-á, portanto, como acontecer concreto da circularidade do ser-aí, emergindo da ambivalência que perpassa a faticidade do ser-aí enquanto mergulhado na verdade e na não-verdade, no velamento e desvelamento". STEIN, Ernildo. Compreensão e Finitude: estrutura e movimento da interrogação heideggeriana. Ijuí: Ed. Unijuí, 2001, pp. 276-277.

${ }^{24}$ HEIDEGGER, Martin. Ser e Tempo. Trad. Márcia de Sá Cavalcante Schuback. 3. Ed. Petrópolis: Vozes; Bragança Paulista: Editora Universitária São Francisco, 2008, pp. 214-5.

${ }^{25}$ É a posição da doutrina, dentre outros, de Ernildo Stein e Lenio Streck.

${ }^{26}$ Heidegger salienta que sua obra Ser e Tempo que "A interpretação funda-se existencialmente no compreender e não vice-versa. Interpretar não é tomar conhecimento do que se compreendeu, mas elaborar as possibilidades projetadas no compreender (...). A interpretação de algo como algo funda-se, essencialmente, numa posição prévia, visão prévia e concepção prévia. A interpretação nunca é apreensão de um dado preliminar, isenta de pressuposições". HEIDEGGER, Martin. Ser e Tempo. Trad. Márcia de Sá Cavalcante Schuback. 3. Ed. Petrópolis: Vozes; Bragança Paulista: Editora Universitária São Francisco, 2008, p. 209-11. 
que deságua na applicatio, isto é, na aplicação do Direito à situação concreta pelo intérprete. Assim, interpretar e aplicar são coisas incindíveis ${ }^{27}$.

Há um encurtamento hermenêutico, mediante a rejeição das "verdades eternas" e das "leis naturais", com a superação da metafísica, além da proposta da superação da relação sujeitoobjeto, que busca apoio nas teorias da consciência, discutindo-se uma nova questão do método, qual seja, a analítica existencial, como projeto de Ser e Tempo ${ }^{28}$.

Afinal, é preciso de um método para a concretização da decisão jurídica democrática?

A hermenêutica filosófica, ao decretar a "morte" do método, não se mostra, por isso, consentânea com o irracionalismo ou com o subjetivismo arbitrário. Ao revés, designadamente em face de tal constatação - a crise do método - é que o intérprete precisa ancorar-se na tradição que decorre do processo histórico e da consciência dos efeitos da história nos institutos e na tomada de decisão ${ }^{29}$. Ademais, o caráter alográfico do Direito demanda um esforço por parte do hermeneuta para a concretização normativa em atenção aos balizamentos constitucionais, diante da diferença entre texto e norma.

A alteridade hermenêutica finca raízes na necessária escuta do texto, no fato de que o intérprete tem de deixar que o texto lhe diga algo ${ }^{30}$, para que o mesmo

${ }^{27}$ Streck ensina que "Consciência e mundo, linguagem e objeto, sentido e percepção, teoria e prática, texto e norma, vigência e validade, regra e princípio, casos simples e casos difíceis, discursos de justificação e discursos de aplicação: esses dualismos se instalaram no nosso imaginário sustentados pelo esquema sujeito-objeto. E a tarefa de um discurso crítico é a de mostrar essa incindibilidade e que há sempre algo que nos antecede, que é a dimensão da linguagem, que é condição de possibilidade. Para que o ôntico nos apareça, há um algo (pré)ontológico que nos antecipa o sentido. Aí está a pré-compreensão, e esta é impossível de negar, mesmo que obedeçamos a todos os procedimentos necessários para a conformação de uma verdade consensual. No ser-nomundo, no mundo prático, está a superação do paradigma epistemológico. Afinal, é exatamente por isso que interpretar e aplicar são coisas incindiveis" STRECK, Lenio Luiz. "Da interpretação de Textos à Concretização de Direitos: a incindibilidade entre interpretar e aplicar a partir da diferença ontológica (ontologische differentz) entre texto e norma." Constituição, Sistemas Sociais e Hermenêutica. Programa de Pós-Graduação em Direito da UNISINOS. Mestrado e Doutorado em Direito. Anuário 2005, n. ${ }^{\circ}$ 2, (Org.) André Copetti, Lenio Luiz Streck e Leonel Severo Rocha. Porto Alegre: Livraria do Advogado, 2006, p. 178-9.

${ }^{28}$ STEIN, Ernildo. Seis Estudos sobre “Ser e Tempo”. 4. ed. Petrópolis: Vozes, 2008, p. 32-3.

${ }^{29}$ Conforme refere Lamego, o conceito de verdade, na perspectiva existencial-hermenêutica de Gadamer, "não é uma aproximação metodicamente dirigida a um ideal de objectividade, mas antes a revelação de sentido que resulta da „fusão dos horizontes"e (Verschmelzung der Horizonte). A interpretação não se acaba num conhecer, mas é um agir mediador, potenciando as possibilidades da „coisa" ${ }^{\text {e" }}$. LAMEGO, José. Hermenêutica e Jurisprudência. Análise de uma "recepção". Lisboa: Fragmentos, 1990, pp. 193-194.

${ }^{30}$ Para Gadamer, "A tarefa hermenêutica se converte por si mesma num questionamento pautado na coisa em questão, e já se encontra sempre co-determinada por esta. Assim, o empreendimento hermenêutico ganha um solo firme sob seus pés. Aquele que quer compreender não pode se entregar de antemão ao arbítrio de suas próprias opiniões prévias, ignorando a opinião do texto da maneira mais obstinada e consequente possível - até que este acabe por não poder ser ignorado e derrube a suposta compreensão. Em princípio, quem quer compreender um texto deve estar disposto a deixar que este lhe diga alguma coisa. Por isso, uma consciência formada hermeneuticamente deve, desde o princípio, mostrar-se receptiva à alteridade do texto. Mas essa receptividade não pressupõe nem uma „neutralidade com relação à coisa nem tampouco um autoanulamento de si mesma; implica antes uma destacada apropriação das opiniões prévias e 
possa aplicar a norma sem incorrer em ideias ou opiniões arbitrárias, mediante a suspensão dos pré-juízos inautênticos, nomeadamente na seara dos direitos sociais. Na lição de Rocha, em uma leitura sistêmica voltada ao controle sobre as decisões, o Poder Judiciário é uma organização e não pode mais ser visto como "a figura isolada de um juiz (...). Não se pode ter uma noção amadora de uma organização séria como o Judiciário que dependa da subjetividade das pessoas ou da sua boa vontade" ${ }^{\text {31 }}$.

A linguagem, como ensina Heidegger ${ }^{32}$, é a casa do ser, sendo que os pensadores e os poetas são os seus vigilantes, razão pela qual assume relevo na construção de um sentido autêntico da Constituição, não sendo um mero objeto ou instrumento que se coloca entre o sujeito e o objeto.

Nessa senda, Gadamer ${ }^{33}$ refere que o "Ser que pode ser compreendido é linguagem". O ser do ente "Constituição" se desvela no caso concreto, na perspectiva da implementação dos direitos fundamentais sociais, ou seja, não é suficiente reconhecer a força normativa da Lei Maior se não são aplicados os seus princípios e regras que balizam a interpretação.

O juiz tem responsabilidade política por suas decisões (Dworkin), de tal maneira que assume relevo um dever de accountability, que se concretiza pelo dever constitucional de fundamentação das decisões, nos termos do artigo 93, inciso IX, da Constituição Federal. Toda interpretação deve guardar-se da “arbitrariedade dos „chutes ${ }^{\text {ee }}$ e do caráter limitado de hábitos mentais inadvertidos, de maneira a voltar-se „para as coisas elas mesmas ${ }^{\text {ee }} 34$. Logo, aquele que quiser compreender um texto deve estar "disposto a deixar que ele diga alguma coisa. Por isso, uma consciência formada hermeneuticamente deve ser de antemão receptiva à alteridade do texto" ${ }^{, 35}$.

\footnotetext{
preconceitos pessoais". GADAMER, Hans-Georg. Verdade e Método I. Traços fundamentais de uma hermenêutica filosófica. Trad. Flávio Paulo Meures. Petrópolis: Vozes, 1997, p. 358; grifos nossos.

${ }^{31}$ ROCHA, Leonel Severo. Epistemologia Jurídica e Democracia. 2. ed. São Leopoldo: Editora Unisinos, 2005, p. 198. Em tal perspectiva, o autor se aproxima da ideia do "romance em cadeia", de Ronald Dworkin.

32 HEIDEGGER, Martin. Sobre o Humanismo. Trad. Emmanuel Carneiro Leão. 3. Ed. Rio de Janeiro: Tempo Brasileiro, 2009, pp. 24-5.

${ }_{33}$ Consoante Gadamer, "O intérprete não se serve das palavras e dos conceitos como o artesão que apanha e deixa de lado suas ferramentas. Precisamos, antes, reconhecer que toda compreensão está intimamente entretecida por conceitos e refutar qualquer teoria que se negue a aceitar a unidade interna de palavra e coisa". GADAMER, Hans-Georg. Op. cit., p. 522.

${ }^{34}$ GADAMER, Hans-Georg. Verdade e Método II: complementos e índice. Trad. Ênio Paulo Giachini. 6. ed. Petrópolis: Vozes, 2011, p. 74-75.

${ }^{35}$ GADAMER, Hans-Georg. Op. cit., p. 76.
} 


\section{COERÊNCIA E INTEGRIDADE À LUZ DE "MEDIDA POR MEDIDA", DE SHAKESPEARE. AFINAL, QUAL A RESPOSTA ADEQUADA À CONSTITUIÇÃO?}

Para além de questionar as estruturas do poder e a vinculação aos direitos humanos e fundamentais, a interpretação da Constituição deve apontar, na intersubjetividade e mediante a adoção dos "jogos de linguagem” (Wittgenstein) que a construção jurídica não pode se fiar na "vontade" do intérprete, a qual precisa ser desvelada pela compreensão dos "caminhos da floresta" (Heidegger) do texto constitucional.

Em sua teoria integrativa do Direito, Dworkin sustenta que o fenômeno jurídico compõe-se de um complexo de coerência de princípios relativos à justiça, à equanimidade e ao devido processo legal adjetivo, pedindo aos juízes que "os apliquem nos novos casos que se lhes apresentem, de tal modo que a situação de cada pessoa seja justa e eqüitativa segundo as mesmas normas" 36

Uma concepção é melhor que outra quando "mais se ajusta adequadamente („Fit") aos paradigmas socialmente compartilhados desse mesmo conceito e é capaz de descrever as práticas paradigmáticas de maneira mais coerente". A melhor justificação deve estar alicerçada em critérios de "integridade, economicidade argumentativa e coerência", sendo importante assinalar que tal procedimento "não elimina a controvérsia, antes oferece uma teoria da controvérsia sem a qual não conseguimos bem descrever o que é o Direito",37.

Em face disso, não se pode admitir o argumento falacioso consistente na leitura segundo a qual, se não há fórmula mecânica para distinguir as boas e as más decisões, e os juristas e juízes irão divergir em um caso complexo ou difícil, nenhum argumento é melhor do que o outro, razão pela qual seria uma perda de tempo o raciocínio jurídico. Ao revés, deve-se insistir em um princípio que parte da ideia, inerente ao conceito de direito, de que quaisquer que sejam os pontos de vista acerca da justiça e da equidade, os juízes devem aceitar "uma restrição independente e superior, que decorre da integridade, nas decisões que tomam"38.

Como se interpreta em Direito ou, mais especificamente, qual o papel dos princípios na interpretação jurídica?

O processo de produção de sentido normativo, permeado pela interpretação, reclama uma leitura adequada do contributo teórico da diferenciação entre princípios e regras, de

\footnotetext{
${ }^{36}$ DWORKIN, Ronald. O Império do Direito. Trad. Jefferson Luiz Camargo. 2. ed. São Paulo: Martins Fontes, 2007, p. 291. ${ }^{37}$ MACEDO JÚNIOR, Ronaldo Porto. "Como levar Ronald Dworkin a sério ou como fotografar um porco- espinho em movimento”. (Apresentação). In: GUEST, Stephen. Ronald Dworkin. Trad. Luís Carlos Borges: Rio de Janeiro: Elsevier, 2010. ${ }^{38}$ DWORKIN, Ronald. Domínio da Vida: aborto, eutanásia e liberdades individuais. Trad. Jefferson Luiz Camargo. 2. ed. São Paulo: Martins Fontes, 2009, pp. 203-204.
} 
modo a que a dimensão principiológica não seja tomada por um manejo inapropriado que pode comprometer a autonomia do Direito.

$\mathrm{Na}$ doutrina, o recurso aos princípios tem funcionado como uma "panaceia" para a resolução dos casos "difíceis", sendo que as regras acabam exercendo um papel de menor importância, ou, por vezes, deixadas de lado no processo interpretativo.

A ideia ou o conceito de "princípio" assume forte carga simbólica e conteúdo deontológico, espelhando os indícios formais (Heidegger) da decisão jurídica democrática ${ }^{39}$.

O princípio, na lição de Dworkin, “é um padrão que deve ser observado, não porque vá promover ou assegurar uma situação econômica, política ou social considerável desejável, mas porque é uma exigência de justiça ou equidade ou alguma outra dimensão da moralidade" ${ }^{\$ 4}$. Os princípios são padrões de argumentação responsáveis pela abertura do direito ao mundo prático, conforme ensina Streck. Nessa linha de raciocínio, a acertada crítica do referido doutrinador àquilo que denomina de "pamprincipiologismo", ou seja, o incremento dogmático de pautas de argumentação com pretensão valorativa, em um retorno à vetusta jurisprudência dos valores, os quais contribuem para o aumento do poder discricionário judicial.

A noção de livre convencimento motivado significa conferir ao juiz o poder discricionário de avaliar a prova dos autos segundo a sua própria consciência, ainda que, após, decline os motivos de tal convicção. Em síntese, a motivação surge como uma espécie de “capa de sentido", âmbito no qual é possível dizer-se "qualquer coisa sobre qualquer coisa”, em uma "jurisdição dos conceitos sem coisas", isto é, despida da historicidade e da faticidade (Streck).

Luigi Ferrajoli e Lenio Streck, entre outros, sustentam que os princípios, em realidade, "fecham" a interpretação, razão pela qual devem ser vistos em uma relação de complementaridade com as regras. Não há princípio sem regra, tampouco regra sem princípio (Streck). Não pode o intérprete ignorar a natureza das regras jurídicas, suspendendo eventuais

\footnotetext{
${ }^{39}$ Conforme Tomaz de Oliveira, "O conceito de princípio funciona assim como uma espécie de indício formal: em todos os casos conflituosos há uma possibilidade de um argumento de princípio. Afinal, será possível imaginar um caso hipotético em que não estaria em jogo, ou pudesse ser arguido em favor de um dos oponentes, o princípio da igualdade? Poderia haver um processo em que as discussões não violassem o devido processo legal?" Assevera o autor, ainda, que "No momento em que se tem uma quebra com esse elo que o passado nos lega, há a necessidade de uma intensa justificação, que não exclua de sua apreciação a comum-unidade dos princípios e sempre fundamente, na medida em que for necessário, em que medida tais princípios estão observados pela decisão. Assim, estabelece o direito como integridade de Ronald Dworkin." OLIVEIRA, Rafael Tomaz de. Decisão judicial e o conceito de principio. A hermenêutica e a (in)determinação do Direito. Porto Alegre: Livraria do Advogado, 2008, p. 238. ${ }^{40}$ DWORKIN, Ronald. Levando os Direitos a Sério. Trad. Nelson Boeira. São Paulo: Martins Fontes, 2002, p. 36.
} 
pré-juízos inautênticos que associam as regras a uma postura autoritária e os princípios aos sopros da democracia. Ao revés, vale dizer que uma demasiada abertura do Direito, diante das zonas de penumbra (Hart), contribuiu, no curso da história, para a formação de correntes de pensamento como a Escola do Direito Livre, a Jurisprudência dos Interesses e a Jurisprudência dos Valores, servindo de fundamento para legitimar a instituição de regimes totalitários, baseados no "espírito do povo" (o nazismo de Hitler, na Alemanha, e o fascismo de Mussolini, na Itália) ${ }^{41}$.

Por sua vez, princípios não são valores e, por isso, possuem natureza deontológica e não axiológica. Vinculam o intérprete e a decisão judicial, de tal modo que devem ser levados a sério no ato de julgar como virtudes soberanas (Dworkin). Cumpre observar, na esteira de Streck, que a "prevalência da regra em face de um princípio significa um retorno ao positivismo, além de independentizar a regra de qualquer princípio (e vice-versa), como se fosse um objeto dado (posto) "42, quadro que implica a discricionariedade, ficando a cargo do juiz a “„escolha das hipóteses ${ }^{\text {ee }}$ em que uma regra é independente de um princípio e em que a regra prevalecerá diante do princípio" "43. Assinala, ainda, que o "novo paradigma de direito instituído pelo Estado Democrático de Direito proporciona a superação do direito-enquantosistema-de-regras, fenômeno que (somente) se torna possível a partir dos princípios de resgate no mundo prático (faticidade) até então negado pelo positivismo (...)"44.

Reportando-se ao caso concreto (genro que mata o sogro e postula a meação da herança), o artigo 1591, inciso I, do Código Civil de 1916 tinha a seguinte redação:

“Art. 1.595. São excluídos da sucessão (arts. 1.708, IV, e 1.741 a 1.745), os herdeiros, ou legatários:

I - que houverem sido autores ou cúmplices em crime de homicídio voluntário, ou tentativa deste, contra a pessoa de cuja sucessão se tratar".

\footnotetext{
41 Entre outros, Larenz entende que "é a própria Constituição que torna obrigatória a observância de determinados valores e referências de sentido", defendendo um pensamento compreensivo e orientado a valores. LARENZ, Karl. Metodologia da Ciência do Direito. Trad. José Lamego. 5. ed. Lisboa: Fundação Calouste Gulbenkian, 2009, p. 512. Como refere Lamego, "se KARL LARENZ opera no pós-guerra uma ruptura com a sua fundamentação neo-hegeliana de uma „renovação alemã do Direito" (deutche Rechterneuerung) de cariz totalitário, em direcção a um personalismo ético de pendor institucionalista, e se acaba mesmo por abandonar uma fundamentação neo-hegeliana de um pensamento jusmetodológico „compreensivo" e orientado a valores, subsiste nele uma tendência de oposição ao método analítico-abstracto de construção e desenvolvimento do Direito no sentido de um pensamento „holístico" (ganzheitliches Denken)”. LAMEGO, José. "Nótula do Tradutor". "Um filho do seu tempo". in LARENZ, KARL. Op. cit., p. 708.

${ }^{42}$ STRECK, Lenio Luiz. Verdade e Consenso. Constituição, Hermenêutica e Teorias Discursivas. 4. ed. São Paulo: Saraiva, 2012, p. 177.

${ }^{43}$ STRECK, Lenio Luiz. Op. cit., p. 177.

${ }^{44}$ STRECK, Lenio Luiz. Hermenêutica Jurídica $e(m)$ Crise: uma exploração hermenêutica da construção do Direito. 11. ed. rev. amp. atual. Porto Alegre: Livraria do Advogado, 2014, p. 408.
} 
A esse respeito, vale lembrar que, no caso Elmer (Riggs v. Palmer), tratado por Dworkin em sua obra Levando os Direitos a Sério, envolvia situação na qual o neto assassinou o avô e buscava herdar o acervo do de cujus, valendo-se justamente da ausência de previsão legal a respeito do assunto. Todavia, o princípio que veda que uma pessoa se beneficie de sua própria torpeza ou da proibição do locupletamento ilícito, decorrente da ideia de igual consideração e respeito devido aos cidadãos que compartilham uma comunidade de princípios, mereceu acolhimento no referido caso para afastar o neto da sucessão hereditária por indignidade.

A decisão do Tribunal de Justiça do Rio Grande do Sul, no caso do genro que mata o sogro e que pretende sua meação na herança, em face do regime da comunhão universal de bens, oscila entre os modelos de fundamentação "Ângelo I" e "Ângelo II", sendo que sua "medida" não observou a perspectiva traçada pelo fairness, compreendido como equanimidade (“jogo limpo"), tampouco a coerência e a integridade do Direito. O caso concreto revela nítida frustração ou ruptura de expectativas legítimas normativas, porquanto o Direito é um complexo coerente e íntegro e regras e princípios, os quais são padrões interpretativos de moralidade política que, em síntese, "fecham a interpretação", como lembram Ferrajoli e Streck.

A moral adotada pelo TJRS foi a decorrente do senso comum ou a moral vulgar, ou seja, o senso de justiça do magistrado, quadro que possibilita a adoção de juízos discricionaristas do tipo "decido conforme a minha consciência" (Streck). A reconstrução da história institucional tem uma valiosa dimensão temporal, pois deve projetar os limites da interpretação para os casos futuros, o que não foi alvo de preocupação no caso em tela. Se diante da ausência de regra, admitir-se a solução discricionária adotada pelo positivismo jurídico, em especial por Kelsen em sua Teoria Pura do Direito (oitavo capítulo), e por Hart em sua obra O Conceito de Direito, o qual admite o poder discricionário judicial em face da textura aberta da norma, haverá uma nítida fragilização da autonomia do Direito, que cederá lugar às "escolhas" subjetivas do julgador.

Streck, em sua obra Verdade e Consenso, assinala a existência de cinco princípios ou padrões interpretativos para a resposta constitucionalmente adequada. Assim, a teoria do Direito e da Constituição reclama os seguintes parâmetros hermenêuticos: a) a preservação da autonomia do direito; b) o estabelecimento de condições hermenêuticas para a realização de um controle da interpretação constitucional; c) a garantia do respeito à integridade e à coerência do Direito; d) o dever de fundamentação das decisões judiciais; e e) a garantia que 
cada cidadão tenha sua causa julgada a partir da Constituição e que haja condições para aferir se essa resposta está ou não constitucionalmente adequada ${ }^{45}$.

Em sua tese de doutoramento, Motta ${ }^{46}$, partindo do referencial teórico da Crítica Hermenêutica do Direito, de Streck, e da obra de Dworkin, afirma que a resposta correta ou boa resposta tem uma dupla dimensão (procedural e substancial), ressaltando a importância de uma teoria da responsabilidade moral como virtude no ato de julgar, ou seja, aquilo que Dworkin denomina de epistemologia moral.

Vale trazer a lume o seguinte recorte do pensamento do autor:

\begin{abstract}
(...) não há como demonstrar que um argumento moral é correto; não há como sustentá-lo sem pressupor ou aceitar outros argumentos morais. O que se pode, repetese, é exigir de quem o formula a referida responsabilidade. Insistindo no exemplo acima, nós podemos estar certos, por hipótese, com relação à justiça das cotas raciais tendo formado a nossa opinião num jogo de cara-ou-coroa, e estarmos errados, quanto a este mesmo assunto, depois de uma demorada reflexão. Contudo, teríamos sido irresponsáveis no primeiro caso e responsáveis no segundo. E a distinção entre um e outro argumento passa a ser o tema dessa almejada teoria da responsabilidade.

É o que o autor chama de epistemologia moral. Em síntese, é uma espécie de teoria da responsabilidade moral, mediante a qual possamos conferir se nosso raciocínio moral é bom ou mau - o que, também, diga-se, é uma questão moral substantiva. Utiliza-se parte de uma teoria geral do valor para conferir a integridade do raciocínio no restante. O ponto defendido por Dworkin, aqui, já deve ter ficado claro: ele está defendendo que o raciocínio moral deve ser interpretativo ${ }^{47}$.
\end{abstract}

\title{
CONCLUSÃO
}

Na obra "Medida por Medida", de Shakespeare, os "modelos de juiz" simbolizados no personagem Ângelo apontam para o problema do positivismo jurídico: ora o apelo ao exegetismo/fetichismo legalista como bússola interpretativa (Ângelo I), ora a desvinculação plena do texto em relação à norma "produzida" na construção hermenêutica, em nome do livre convencimento ou da discricionariedade judicial (Ângelo II).

A chave de leitura está justamente na tese dos direitos, propugnada por Ronald Dworkin. Segundo o referido jusfilósofo, é necessário fazer uma distinção entre argumentos de princípio e argumentos de política: decidir por política implica em atender a determinadas metas ou conveniências, ao passo que decidir por princípio leva ao cuidado com os direitos,

\footnotetext{
45 STRECK, Lenio Luiz. Verdade e Consenso. Constituição, Hermenêutica e Teorias Discursivas. 4. ed. São Paulo: Saraiva, 2011, pp. 585-587.

${ }^{46}$ MOTTA, Francisco José Borges. Ronald Dworkin e a construção de uma teoria hermeneuticamente adequada da decisão jurídica democrática. Tese de doutoramento em Direito. Unisinos, São Leopoldo, 2014.

${ }^{47}$ MOTTA, Francisco José Borges. Op. cit., pp. 40-41.
} 
os quais devem ser levados a sério pelo intérprete! A discricionariedade, por sua vez, está associada à ideia de escolha, nos campos político, moral ou econômico.

Toda interpretação é imbuída de um propósito, devendo procurar uma reconstrução da história institucional, a partir da coerência e da integridade do direito, compreendido como uma prática social argumentativa e, ao mesmo tempo, como um todo coerente e íntegro. Não há, pois, espaço válido para relativismos ou ceticismos a partir de argumentos metajurídicos de política ou mesmo de moral, sob pena de uma fragilização da autonomia do direito e, com isso, da democracia.

Ora, o texto é estático, ao passo que a norma é dinâmica, salienta Müller ${ }^{48}$, em sua teoria estruturante do direito. A norma é composta pelo programa normativo e pelo âmbito da norma, este último um autêntico recorte da realidade social, a permear o processo de construção interpretativa.

Em realidade, deve o juiz pautar-se pelos limites semânticos dos textos, sobretudo a Constituição, e não pelo "livre convencimento" motivado, o qual reclama uma (des)construção hermenêutica à luz do direito fundamental ao juiz imparcial e ao dever de fundamentação da fundamentação (Streck). Não pode descuidar, ainda, do "romance em cadeia" (Dworkin) e da tradição autêntica em torno do direito/dever de se obter respostas constitucionalmente adequadas.

Por conseguinte, à luz das razões esposadas, a decisão adotada pelo Tribunal de Justiça no caso do genro que assassina o sogro e que pretende a meação da herança, em que pese tenha atingido a solução acertada ao caso, pautou-se por uma moral comum ou vulgar e não pela ideia de moralidade política da comunidade, de maneira que não se orientou pelos ideais de coerência, integridade, responsabilidade e de accountability hermenêutico, em face da fragilidade dos fundamentos adotados, apostando no poder discricionário judicial.

\section{REFERÊNCIAS}

BLACKBURN, Simon. Dicionário Oxford de Filosofia. Trad. Trad. Desidério Murcho et al. Rio de Janeiro: Zahar, 1997.

\footnotetext{
${ }^{48}$ MÜLLER, Friedrich. Métodos de trabalho no direito constitucional. 3. ed. rev. amp. Rio de Janeiro: Renovar, 2005, p. 160 e MÜLLER, Friedrich. Teoria Estruturante do Direito. Trad. Peter Naumann. São Paulo: Revista dos Tribunais, 2008, p. 192-193.
} 
Fontes, 2002.

DWORKIN, Ronald. Levando os direitos a sério. Trad. Nelson Boeira. Martins

DWORKIN, Ronald. O Império do Direito. Trad. Jefferson Luiz Camargo. 2. ed. São Paulo: Martins Fontes, 2007.

DWORKIN, Ronald. Domínio da Vida: aborto, eutanásia e liberdades individuais. Trad. Jefferson Luiz Camargo. 2. ed. São Paulo: Martins Fontes, 2009.

ENGISCH, Karl. Introdução ao Pensamento Jurídico. Trad. João Baptista Machado. 10 ed. Lisboa: Fundação Calouste Gulbenkian, 2008.

FERRAJOLI, Luigi. Direito e Razão. Teoria do Garantismo Penal. Trad. Ana Paula Zomer Sica et all. 2. ed. rev. amp. São Paulo: Revista dos Tribunais, 2006.

GADAMER, Hans-Georg. Verdade e Método I. Traços fundamentais de uma hermenêutica filosófica. Trad. Flávio Paulo Meures. Petrópolis: Vozes, 1997.

. Verdade e Método II: complementos e índice. Trad. Ênio Paulo Giachini. 6. ed. Petrópolis: Vozes, 2011.

HEIDEGGER, Martin. Ser e Tempo. Trad. Márcia de Sá Cavalcante Schuback. 3. Ed. Petrópolis: Vozes; Bragança Paulista: Editora Universitária São Francisco, 2008.

. Sobre o Humanismo. Trad. Emmanuel Carneiro Leão. 3. ed. Rio de Janeiro: Tempo Brasileiro, 2009.

KELSEN, Hans. Teoria Pura do Direito. Trad. João Baptista Machado. São Paulo: Martins Fontes, 2011.

. “O que é positivismo jurídico?”. Direito Natural, Direito Positivo, Direito Discursivo. Alexander Hollerbach et al.; Luís Afonso Heck (org. e trad.). Porto Alegre: Livraria do Advogado, 2010, pp. 85-94.

LAMEGO, José. Hermenêutica e Jurisprudência. Análise de uma "recepção". Lisboa: Fragmentos, 1990.

LARENZ, Karl. Metodologia da Ciência do Direito. 5. ed. Trad. José Lamego. Lisboa: Fundação Calouste Gulbenkian, 2009.

LOSANO, Mário. Sistema e estrutura do Direito: O século XX. Trad. Luca Lamberti. São Paulo: Martins Fontes, volume 2, 2010.

MACEDO JÚNIOR, Ronaldo Porto. "Como levar Ronald Dworkin a sério ou como fotografar um porco-espinho em movimento". (Apresentação). In: GUEST, Stephen. Ronald Dworkin. Trad. Luís Carlos Borges: Rio de Janeiro: Elsevier, 2010.

MERRYMAN, John Henry; PÉREZ-PERDOMO, Rogelio. A Tradição da Civil Law. Uma introdução aos Sistemas Jurídicos da Europa e da América Latina. Trad. Cássio Casagrande. Porto Alegre: Sergio Antonio Fabris Editor, 2009. 
MOTTA, Francisco José Borges. Ronald Dworkin e a construção de uma teoria hermeneuticamente adequada da decisão jurídica democrática. Tese de doutoramento em Direito. Unisinos, São Leopoldo, 2014.

MÜLLER, Friedrich. Métodos de trabalho no direito constitucional. 3. ed. rev. amp. Rio de Janeiro: Renovar, 2005. Tribunais, 2008 . . Teoria Estruturante do Direito. Trad. Peter Naumann. São Paulo: Revista dos

OLIVEIRA, Manfredo Araújo de. Reviravolta linguístico-pragmática na filosofia contemporânea. 3. ed. São Paulo: Loyola, 2006.

OLIVEIRA, Rafael Tomaz de. Decisão judicial e o conceito de principio. A hermenêutica e a (in)determinação do Direito. Porto Alegre: Livraria do Advogado, 2008.

ROCHA, Leonel Severo. Epistemologia Jurídica e Democracia. 2. ed. São Leopoldo: Editora Unisinos, 2005.

SHAKESPEARE, William. Medida por Medida. Ed. Ridendo Castigat Mores. Disponível em: 〈www.jahr.org〉. Acesso em 5 de agosto de 2015. 2001 .

STEIN, Ernildo. Epistemologia e Crítica da Modernidade. 3. ed. Ijuí. Ed. Unijuí,

Compreensão e Finitude: estrutura e movimento da interrogação heideggeriana. Ijuí: Ed. Unijuí, 2001. . Seis Estudos sobre "Ser e Tempo”. 4. ed. Petrópolis: Vozes, 2008.

STRECK, Lenio Luiz. "Da interpretação de Textos à Concretização de Direitos: a incindibilidade entre interpretar e aplicar a partir da diferença ontológica (ontologische differentz) entre texto e norma." Constituição, Sistemas Sociais e Hermenêutica. Programa de Pós-Graduação em Direito da UNISINOS. Mestrado e Doutorado em Direito. Anuário 2005, n. ${ }^{\circ}$ 2, (Org.) André Copetti, Lenio Luiz Streck e Leonel Severo Rocha. Porto Alegre: Livraria do Advogado, 2006.

. Verdade e Consenso. Constituição, Hermenêutica e Teorias Discursivas. 4. ed. São Paulo: Saraiva, 2012.

O que é isto - decido conforme minha consciência? 4. ed. rev. Porto Alegre: Livraria do Advogado, 2013.

- Hermenêutica Jurídica e(m) Crise: uma exploração hermenêutica da construção do Direito. 11. ed. rev. amp. atual. Porto Alegre: Livraria do Advogado, 2014.

WITTGENSTEIN, Ludwig. Investigações Filosóficas. Trad. Marcos G. Montanoli. 7. ed. Petrópolis: Vozes: Bragança Paulista: Editora Universitária São Francisco, 2012. 